G

OPEN ACCESS

Citation: Santaella T J. Colomb Med (Cali). 2020; 51(2):e-4272. http://doi. org/10.25100/cm.v51i2.4272

Received : 02 Apr 2020

Revised : 25 Apr 2020

Accepted : 04 May 2020

Published: 11 May 2020

Keywords:

COVID-19, Drug repositioning, Pandemic, drugs, Therapeutic alternatives Coronavirus infections, SARS-CoV-2, COVID-19 diagnostic testing, Polymerase Chain Reaction, sensitivity and specificity

Palabras clave:

Infección por Coronavirus, SARSCoV-2, Prueba diagnóstica COVID-19, Reacción en cadena de la polimerasa, sensibilidad y especificidad

Copyright: (c) 2020. Universidad del Valle.

(c) (1) $(5)$
REVIEW

\section{SARS-CoV-2 diagnostic testing alternatives for Latin America}

\section{Alternativas diagnósticas para SARS-CoV-2 para América Latina}

Julián Santaella-Tenorio

julian.santaella@correounivalle.edu.co

1. Universidad del Valle, Facultad de Salud, Escuela de Salud Pública, Cali, Colombia, 2. Pontificia Universidad Javeriana, Maestría en Epidemiología Clínica Cali, Colombia,

\section{Abstract}

In the past four months SARS-CoV-2 has reached most countries in the world. Public health strategies based on widespread testing and proper isolation of positive cases have shown to be helpful to reduce local transmission of SARS-CoV-2. Confirmatory tests, that identify viral RNA, and screening serological tests that identify viral antigens or host antibodies against viral proteins are part of the tools that nations can use to fight infectious disease epidemics. Understanding how each test works can provide insights about their test characteristics and how they can be used for different clinical and public health goals. Testing is a key strategy to reduce viral transmission, not only for this epidemic, but also for others to come.

\section{Resumen}

En los últimos cuatro meses, el virus SARS-CoV-2 ha llegado a la mayoría de países en el mundo. Las estrategias de salud pública basadas en la realización masiva de pruebas diagnósticas y el aislamiento focalizado de casos positivos han demostrado ser útiles para la reducción de la transmisión de SARS-CoV-2. Las pruebas confirmatorias, que identifican el ARN viral, y las pruebas serológicas que identifican antígenos virales o anticuerpos contra las proteínas virales del huésped son herramientas que las naciones pueden usar para combatir las epidemias producidas por agentes infecciosos. El comprender cómo funcionan estas pruebas puede ayudar a entender sus características y cómo pueden ser usadas para diferentes objetivos clínicos y de salud pública. Las pruebas diagnósticas son herramientas clave para reducir la transmisión viral, no solo en esta epidemia, sino para otras por venir. 


\section{Conflict of Interest:}

None

\section{Acknowledgments}

We thank the editors of Colombia Médica for suggestions to improve the quality of the manuscript.

\section{Corresponding author:}

Julian Santaella Tenorio, Universidad del Valle; Escuela de Salud Pública, Facultad de Salud. Cali, Colombia. e-mail: julian. santaella@correounivalle.edu.co

\section{Remark}

\section{Why was this study conducted?}

To provide a summary of available diagnostic tests for SARS-CoV-2 for a better understanding and use of these tests.

\section{What were the most relevant results of the study?}

We describe the different tests that identify viral RNA, viral antigen, and host antibodies against viral antigens; what these tests are useful for and their characteristics.

\section{What do these results contribute?}

This is a summary of diagnostic tests for SARS-CoV-2 that can be used to get a better understanding of the different tests and protocols available for SARS-CoV-2.

\section{Introduction}

In the past four months SARS-CoV-2 has reached most countries in the world. Countries have struggled to slow down its transmission with a common goal to avoid saturation of health care systems and reduce the economic impact of quarantines and other isolation measures. COVID-19 diagnostic testing is an important component of strategies to reduce transmission of SARS-CoV-2 ${ }^{1}$. The world learned from experiences in Singapore, Taiwan, Hong Kong, and South Korea, where screening tests for the general population occurred, that widespread testing help reduce local transmission of SARS-CoV-2. Identification of positive cases can lead to proper timely isolation, adequate monitoring and quarantine of case contacts, and to the implementation of strategies to reduce transmission in health care centers/institutions were cases concentrate (e.g., closure and decontamination of high-risk areas) ${ }^{2}$.

\section{Confirmatory tests}

SARS-CoV-2 infection confirmatory diagnosis is based on polymerase chain reaction (PCR) testing that amplifies and identify viral RNA sequences. In some cases PCR may not be able to detect viral RNA due to early onset of symptoms, issues with sampling and handling of samples, quality of the kit, or test performance ${ }^{3}$. In these cases chest computed tomography has been suggested as a complementary diagnostic tool ${ }^{4,5}$. In January 2020, the WHO designed and started distributing a quantitative reverse-transcriptase-based PCR (RT-PCR) test for detecting SARS-CoV2 ${ }^{1}$. To date, different RT-PCR assays, along with other SARS-CoV-2 diagnostic assays, are available ${ }^{6,7}$ with other tests kits being developed.

RT-PCR testing usually takes 4 to 6 hours to complete, it is complex and requires a high level of laboratory expertise. In addition, RT-PCR is expensive (compared to serological testing) and requires high-level personnel training to obtain and process patient samples, usually lower respiratory tract samples with higher and more prolonged levels of viral RNA, which are more difficult to obtain ${ }^{8}$. Because of these complexities, RT-PCR testing is usually centralized in specialized laboratories. However, testing centralization slows down the identification of cases, as it requires special handling and shipping of clinical samples from regions to the laboratories in major cities. For example, evidence shows that centralized PCR testing in Colombia, at the Instituto Nacional de Salud, during the first weeks of transmission of SARS-CoV-2 in the country lead to important delays (up to 11 days) to obtain confirmatory diagnoses ${ }^{9}$. This slowed down reaction times to conduct public health measures across regions. 
Alternatively, new developments in rapid and automated point-of-care RT-PCR assays (although more costly due to equipment and reagent kits costs) can provide tests results in minutes. For example, the Xpert ${ }^{\circledR}$ Xpress SARS-CoV-2 test (Cepheid) ${ }^{10}$ targets multiple regions of the viral genome and can provide results in 45 minutes using the GenXpert benchtop system. Also, the recent developed Abbott ID NowTM COVID-19 test uses isothermal nucleic acid amplification technology and provides positive results in just 5 minutes ${ }^{11}$. Tests are run in the ID NOW, a small, lightweight and portable platform that can be used in wide range of healthcare settings. To date, the Abbott ID NowTM COVID-19 test is only available in the United States (50,000 tests are being produced every day), but is expected that it will soon be available in other countries.

\section{Antigen testing}

Monoclonal antibodies against SARS-CoV-2 antigens, such as the nucleocapsid (N) protein and the S1 or S2 domains of the spike (S) protein, can also be used to detect viral infection ${ }^{12}$. Antigen testing is performed in lateral flow immunoassays using nasopharyngeal or oropharyngeal swab samples ${ }^{2}$. An advantage of antigen testing is that they are available in rapid test kits that are easy to use and can provide results in 20-60 minutes. However, given that they do not replicate viral RNA sequences, there is concern about their sensitivity ${ }^{2}$ (sensitivity is the ability of a test to identify correctly those with the infection, compared to a gold standard, such as RT-PCR) (Appendix 1$)^{13}$. Also, the development on monoclonal antibodies requires more time than that to develop other tests (e.g., antibody testing), and although promising, accurate tests to identify SARS-CoV-2 antigens are not yet available ${ }^{2,14}$.

\section{Antibody serological immunoassays}

Serological immunoassays are a low-cost alternative that can be widely used at the community level, and that can provide results in 15 to 20 minutes. Serological immunoassays (including rapid lateral flow immunoassay, automated chemiluminescence immunoassay and manual ELISA) ${ }^{15}$ use immobilized recombinant viral proteins/domains of viral proteins to which human antibodies bind if present in the blood. A positive test indicates that the person has antibodies against the virus, offering an indirect measure of past/current viral infection ${ }^{1}$. Because blood samples (including blood from finger pinprick) can be used in these tests, it requires less intensive training to obtain and process samples, and to interpret results. To date, multiple serological test strips, for Immunoglobulin M (IgM) and G (IgG), are available in the market (many more are in the development/certification process), and are being approved for use in different countries ${ }^{1,2,16}$.

Serological immunoassays are considered screening rather than confirmatory tests. Because they measure antibodies in patients' blood, plasma or serum, their sensitivity can vary greatly across disease stages. It is known that antibody response can take several days ${ }^{17}$, for example IgM against SARS-CoV-2 can be first detected, on average, from 5 to 10 days, after the onset of symptoms, and IgG around 10 days after onset of symptoms (Figure 1$)^{17}$. This causes the sensitivity of serological tests to be lower in initial stages of the disease, with a number of those infected with the virus testing negative (false negatives). However, the sensitivity increases as the body produces antibodies against the virus, leading to a reduction in false negatives.

In addition, some individuals exposed to other coronaviruses, but not to SARS-CoV-2, may test positive for SARS-CoV-2 in serological immunoassays (false positives). This occurs because patients' antibodies against viral proteins from other coronavirus can also bind to SARS-CoV-2 proteins used in these tests.

Testing sensitivity and specificity of serological immunoassays vary across available kits. For example, a study shows that the overall testing sensitivity of the COVID-19 IgM/IgG Rapid 


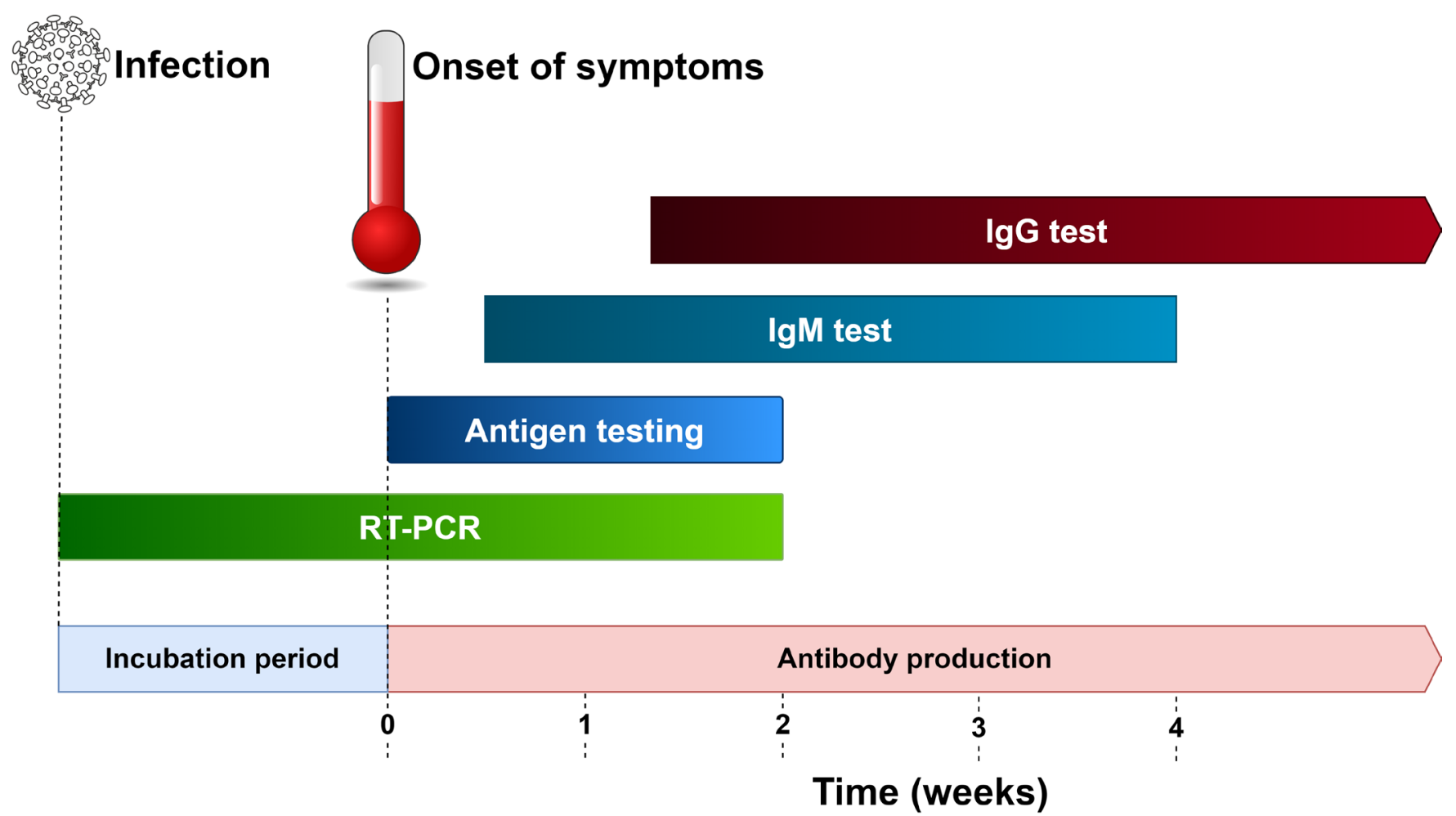

Figure 1. Testing windows for SARS-CoV-2 and antibodies

Test ${ }^{18}$, which simultaneously tests for both $\operatorname{IgM} / \operatorname{IgG}$, was $88.66 \%$ and the specificity $90.63 \%$, when using blood samples from 397 PCR confirmed cases and 128 negative patients ${ }^{18}$. Recent developed rapid lateral flow immunoassay kits also claim to have high sensitivity $(97.2 \%$ $100 \%$ ) and specificity (98-100\%) for IgG, but lower sensitivity (85-91.8\%) and high specificity (96\%-100\%) for IgM ${ }^{19-21}$, although this evidence is not supported by published studies. A recent study conducted in the United States shows evidence of the sensitivity and specificity of different commercial kits ${ }^{22}$. Detailed information on available serological immunoassays for SARS-CoV-2 is available elsewhere ${ }^{1,2,16}$.

Despite the described limitations of serological immunoassays, adding serological tests to the diagnostic toolbox, along and not instead of RT-PCR, is paramount to confront the epidemic, especially considering the complexity of PCR procedures and the common shortages of supplies of key reagents to run these tests ${ }^{2}$. Serological testing can help screen presumptive cases for isolation purposes, but it can also help those with immunity to the virus to leave their homes, get back to work and take care/help others in need. Serologic immunoassays are also useful for ongoing surveillance and studies on vaccine effectiveness ${ }^{7}$. Individuals who are immune to the virus, with detectable antibodies against SARS-CoV-2, could also provide plasma to treat patients, as some studies demonstrate this type of treatment may improve health outcomes in patients with severe respiratory symptoms ${ }^{23,24}$.

In conclusion, multiple available protocols and kits provide solutions to diagnose SARS-CoV-2 infection. Testing is a key strategy to reduce viral transmission, not only for this pandemic, but also for others to come. Countries can be prepared to fight epidemics if they design or acquire appropriate tools to rapidly identify cases of infection, to then conduct appropriate clinical and public health actions that can minimize the burden that high-transmissible and deadly pathogens pose on human populations. 


\section{References}

1. World Health Organization. Coronavirus disease (COVID-19) technical guidance: Laboratory testing for 2019nCoV in humans. Available from: https://www.who.int/emergencies/diseases/novel-coronavirus-2019/technicalguidance/laboratory-guidance. 2020. Accessed April 6, 2020.

2. NUS Saw Swee Hock School of Public Health. COVID-19 Science Report: Diagnostics. 2020. Doi: 10.25540/ e3y2-aqye. Available from: https://sph.nus.edu.sg/wp-content/uploads/2020/03/COVID-19-Science-ReportDiagnostics-30-Mar.pdf Accessed April 6, 2020.

3. Bai Y, Yao L, Wei T, Tian F, Jin DY, Chen L, et al. Presumed Asymptomatic Carrier Transmission of COVID-19. JAMA. 2020;323(14):1406-1407. doi:10.1001/jama.2020.2565

4. Huang P, Liu T, Huang L, Liu H, Lei M, Xu W, et al. Use of Chest CT in Combination with Negative RT-PCR Assay for the 2019 Novel Coronavirus but High Clinical Suspicion. Radiology. 2020;295(1):22-23.

5. Xie X, Zhong Z, Zhao W, Zheng C, Wang F, Liu J. Chest CT for Typical 2019-nCoV Pneumonia: Relationship to Negative RT-PCR Testing. Radiology. 2020:200343.

6. Foundation for Innovative New Diagnostics (FIND). SARS-COV-2 diagnostic pipeline. 2020. Available from : https://www.finddx.org/covid-19/pipeline/. Accessed April 06, 2020.

7. Cheng MP, Papenburg J, Desjardins M, Kanjilal S, Quach C, Libman M, et al. Diagnostic Testing for Severe Acute Respiratory Syndrome-Related Coronavirus-2: A Narrative Review. Ann Intern Med. 2020; doi: 10.7326/ M20-1301

8. Kelly-Cirino C, Mazzola LT, Chua A, Oxenford CJ, Van Kerkhove MD. An updated roadmap for MERS-CoV research and product development: focus on diagnostics. BMJ Glob Health. 2019;4(Suppl 2):e001105.

9. Ospina A. Qué pasa con las pruebas del coronavirus en Colombia?. Caracol Radio. 27/03/2020 19:07 COT. Available from: https://caracol.com.co/radio/2020/03/28/salud/1585353870_152960.html Accessed April 4, 2020.

10. Cepheid. Xpert $₫$ Xpress SARS-CoV-2. has received FDA Emergency Use Authorization. 2020. Available at: https://www.cepheid.com/coronavirus Accessed April 06, 2020.

11. Abbott press releases. Abbott launches molecular point-of-care test to detect novel coronavirus in as little as five minutes. Available from: https://abbott.mediaroom.com/2020-03-27-Abbott-Launches-Molecular-Point-ofCare-Test-to-Detect-Novel-Coronavirus-in-as-Little-as-Five-Minutes. 2020. Accessed April 06, 2020.

12. Sheridan, C. Fast, portable tests come online to curb coronavirus pandemic. Nature Biotechnology. March 23, 2020. Updated April 7, 2020. Available from: https://www.nature.com/articles/d41587-020-00010-2 Accessed April 13, 2020.

13. Gordis L. Epidemology. Fifth ed. Canada: Elsevier Saunders; 2014.

14. Newsfile. Sona Nanotech Provides a Progress Update on its Covid-19 Antigen Test. Available from: https:// www.newsfilecorp.com/release/54361/Sona-Nanotech-Provides-a-Progress-Update-on-its-Covid19-AntigenTest Accessed: April 13, 2020.

15. Kumar VS. In Vitro Diagnostic Assays for COVID-19: Recent Advances and Emerging Trends. Diagnostics. 2020;10(202):1-7.

16. Australian Government Department of Health; Therapeutic COVID-19 test kits included on the ARTG for legal supply in Australia. Available from: https://www.tga.gov.au/covid-19-test-kits-included-artg-legal-supplyaustralia Accessed April 07, 2020. 
17. Tan W, Lu Y, Zhang J, Wang J, Dan Y, Tan Z, et al. Viral kinetics and antibody responses in patients with COVID-19. Medrxiv. 2020; Preprint. Doi: 10.1101/2020.03.24.20042382.

18. Li Z, Yi Y, Luo X, Xiong N, Liu Y, Li S, et al. Development and clinical application of A rapid IgM-lgG combined antibody test for SARS-CoV-2 infection diagnosis. J Med Virol. 2020; 1-7 doi: 10.1002/jmv.25727.

19. Package Insert. ALLTEST 2019-nCoV IgG/lgM rapid test cassette. Hangzhou, China: Hangzhou ALLTEST Biotech Co., Ltd.; 2020.

20. Aytu BioScience Secures Exclusive U.S. Distribution Agreement for Coronavirus 2019 (COVID-19) Point-ofCare Rapid Test. Available from: https://www.accesswire.com/579898/Aytu-BioScience-Secures-Exclusive-USDistribution-Agreement-for-Coronavirus-2019-COVID-19-Point-of-Care-Rapid-Test Accessed April 5, 2020.

21. Accu-Tell. COVID-19 IgG/lgM Rapid Test Cassette. Available from: https://www.accubiotech.com/productcovid-19-igg-igm-rapid-test-cassette-(whole-blood-serum-plasma).html Accessed April 06, 2020.

22. Whitman JD, Hiatt J, Mowery CT, Shy BR, Yu R, Yamamoto TN, et al. Test performance evaluation of SARS-CoV-2 serological assays. medRxiv. 2020; 2020.04.25.20074856. doi: 10.1101/2020.04.25.20074856

23. Shen C, Wang Z, Zhao F, et al. Treatment of 5 Critically III Patients With COVID-19 With Convalescent Plasma. JAMA. 2020; 323(16):1582-1589. doi:10.1001/jama.2020.4783

24. Chen L, Xiong J, Bao L, Shi Y. Convalescent plasma as a potential therapy for COVID-19. Lancet Infect Dis. 2020;20(4):398-400. 


\section{Appendix 1.}

Characteristics of a test: In this example the serological tests is compared to PCR, the gold standard.

\begin{tabular}{llcc}
\hline Serological immunoassay & PCR & Positive & Negative \\
& Positive & a & $\mathrm{b}$ \\
& Negative & c & d \\
\hline
\end{tabular}

Sensitivity: Is the ability of the test to identify correctly those who have the disease/infected. The sensitivity varies by disease stage: for example, it may take several days after infection to develop antibodies against viral proteins, therefore individuals in early stages of disease may test negative in serological tests (false negative). $=\mathrm{a} /(\mathrm{a}+\mathrm{c})$

Specificity: Is the ability of the test to identify correctly those who do not have the disease/not infected. The specificity is affected by the presence, in blood samples, of antibodies against proteins from other viruses that cross-react in serological immunoassays for SARS-CoV-2. $=\mathrm{d} /(\mathrm{b}+\mathrm{d})$

Positive predictive value: Is the proportion of patients with the disease/infected among those with a positive result in the test. The positive predictive value is affected by the prevalence of disease/infection in the population. $=\mathrm{a} /(\mathrm{a}+\mathrm{b})$

Negative predictive value: Is the proportion of patients without disease/not infected among those with a negative result in the test. The negative predictive value is affected by the prevalence of disease/infection in the population. $=\mathrm{d} /(\mathrm{c}+\mathrm{d})$ 